\title{
Linking key success factors of rice supply chain with the operational strategy in Sri Lanka: An analytical framework
}

\author{
W.M.S.K. Weerabahu* and L.D.J.F. Nanayakkara
}

\begin{abstract}
The key success factors of the rice supply chain are regarded as a potentially useful resource in structuring the performance of mud-to-mouth supply chain network. Improving the profitability of the farmer requires adoption of best operational practices for improving the performance of the sector throughout the supply chain. This study mainly focused on identifying the key success factors of the rice supply chain and the presence of those factors in the operational strategy. An exploratory survey was conducted in the Atharagallewa agriculture instructor division of the Polonnaruwa district in Sri Lanka. Randomly selected 50 farmers from a group of 380 and eight agriculture officers were used as the survey participants to identify the current performance and operational strategies in the rice production sector. Based on the statistical analysis of the rankings given by survey participants, key success factors related to mechanization, quality improvement and product development, knowledge and skill development, risk management and information availability of the rice supply chain were identified and were validated with experts' opinion. The analysis helped in developing a Rice Supply Chain Development Ladder (RSCDL). The RSCDL contained three states, namely Introduction, Improvement and Review/Standardization, and facilitated identification of AS-IS state (existing circumstances) of the rice supply chain for the selected study site. These states could differ from district to district, based on the constraints present. This development ladder can be used as an analytical framework to represent the current AS-IS states of the rice supply chain. The RSCDL model provided a structured framework to analyze the current level of operational practices in a high performance rice production area. This can be a useful benchmarking tool for the poorly performing rice growing area with similar environmental conditions.
\end{abstract}

Keywords: AS-IS states, operational strategy, rice supply chain development ladder (RSCDL)

\section{Introduction}

Agriculture is one of the largest contributors to Sri Lanka's GDP and plays a significant role in the rural development. Sri Lanka has achieved self-sufficiency in rice under a critically challenging environment. However, the rice sector in Sri Lanka faces a number of constraints related to production of paddy that could be categorized under socio-economic and policy issues, and technical, institutional and natural resource related issues. In paddy and rice production, it is important to have a collaborative supply chain network and an effective

Department of Industrial Management, University Kelaniya, Sri Lanka

*Sanchala87@gmail.com 
information flow (Copper et al., 1997) throughout the supply chain. Sri Lankan rice/paddy sector is operating in a traditional mode where there is a need to focus on a well-developed supply chain strategy (Croxton et al., 2001a) to ensure competitive positioning/performance of all partners in the chain. From sourceof-supply to the end user, all supply chain activities in rice are inter-dependent and inter-related. From farm-to-table, there is large number of activities to achieve competitiveness in the local and international markets. Improving quality of rice, mechanization of operational processes in the supply chain, facing climate uncertainties are the major challenges of the rice sector in Sri Lanka. This study focused on identifying the key success factors and the links between operational strategy and those success factors of the rice supply chain in Sri Lanka.

\section{Review of Literature}

The Global Supply Chain Forum (GSCF) has defined Supply Chain Management (SCM) as "the integration of key business processes from end user through original suppliers that provides products, services, and information that add value for customer and other stakeholders". Cooper et al. (1997) and Croxton et al. (2001a) identified eight key supply chain (SC) management aspects, which cut across the SC. The GSCF model identified customer relationship management, customer service management, demand management, order fulfillment, manufacturing flow management, supplier relationship management, product development and commercialization and return management are the main SCM aspects. The GSCF model has evolved to complement the need for a comprehensive definition of processes integrating across intercompany boundaries and between functional silos of an organization.

Management of all firms in each SC should consider these eight processes and the relative importance of each process. The specific activities included may vary. Each process has been described at strategic and operational levels. The strategic portion consists of the establishment and management of each process and provides a blueprint for implementation. This is a necessary first step in integrating a firm with other members of the SC. The operational portion is the actualization of the process once it has been established (Croxton et al., 2001a,b). A SC operations reference-model (SCOR) has been developed and endorsed by the Supply-Chain Council (SCC) of the USA as the cross-industry standard for SC management, where the five SCOR processes are plan, source, make, delivery and return (http://supply-chain.org).

The SCOR has been developed for applying and advancing state-of-theart SC management systems and practices through its structured framework and approach. It provides us a comprehensive methodology to improve the overall rice SC operations. The SCOR has a flexible framework and a common language that can improve SC internally and externally by evaluating the 
objectives, effectiveness of reengineering, performance, quantification, testing and future planning of the agriculture sector. Based on the past research (http://supply-chain.org) SCOR model would be the most appropriate mechanism for the rice supply chain with a higher focus on operational efficiency. Hence, the SCOR model was selected in this study for the validation process in the rice supply chain considering only the plan and source processes and their best practices.

\section{Operational strategy}

Sri Lankan rice SC needs cross functional integration and inputs to implement best practices within the sector. Integration among universities, research institutes and industries, and considering the demand patterns and customer requirements as inputs for the development of new rice varieties and paddy cultivation would lead to effective SC strategies. Rice SC constitutes of number of operations that can directly or indirectly lead to the improvements in production and delivery. Operational side of the rice sector refers to the day-today tactics of managing rice cultivation, postharvest practices, etc. The operational strategy looks at the long-term issues on managing resources, which produce products and services. The operational strategy is concerned with the specific decisions, which shape up and develop the long-term direction of the operation (http://wps.pearsoned.co.uk/ema_uk_he_slack_opsman_4/17/ $4472 / 1144851 . \mathrm{cw} /$ ). In developing a strategic mechanism to promote an alternative to present agriculture, knowledge must be gathered from deep rooted customs and traditions, and the time-tested agricultural practices to assure the sustainability in the agricultural sector by integrating and exploiting the up-to-date knowhow and technology. According to the SCOR model, the best practice is a current, structured, proven and repeatable method for making a positive impact on desired operation results. To cater the demand of the rice market and fulfill the rice consumers' expectation, an operational strategy should be implemented with operational best practices.

\section{Key success factors in the rice sector}

Key success factors in the SC are the essential areas of activity that must be performed well to achieve the mission, objectives or goals of the supply chain (https://depts.washington.edu/oei/resources/toolsTemplates/crit_success_facto rs.pdf). The key success factors (KSF) were first introduced by Rockart (1979) as a tool for defining top level managers' information needs. According to Rockart 1979), the KSFs are areas or activities that should receive constant and careful attention from management in order to enhance the current operating activities and for its future success (Leidecker and Bruno, 1984). Besides, KSFs can be applied as a reliable tool for strategic planning, environmental analysis and strategy evaluation. The KSF in rice SC are functions, activities or business practices defined by the rice SC players based on their perspective. Therefore, 
rice supply chain operational strategy depends on the KSF and achievement of SC best practices.

This study mainly focused on identification of rice SCKSF and their presence in the operational strategy. The main research questions to be answered were (1) What are the needs of the farmers \& agricultural officers in order to enhance rice supply chain performance?, (2) What are the key success factors in the rice supply chain? and (3) What are the world class best practices in supply chain management?

\section{Methodology}

A preliminary exploratory survey was carried out with six farmers and an agricultural officer to identify the major needs and suggestions of the farmers about the existing process in the rice SC. A questionnaire was used and data gathering started subsequent to the pilot survey.

With a strong rice SC network that includes high level of technology, highly skilled full time farmers, established irrigation facilities, rice processing villages and factories, Pollonaruwa district Athragallewa agriculture instructor division was selected for data collection. An exploratory survey was conducted with 50 farmers, which were randomly selected from a group of 380 in the Atharagallewa agriculture instructor $(\mathrm{Al})$ division, and eight agriculture officers to identify the current performance and operational strategies in the SC of the rice production sector. In addition to the survey, data were collected from interviews of key informants such as farmers, agriculture officers and experts from paddy sector. Based on the statistical analysis of the rankings given by survey participants, the KSF of the rice SC were identified and validated with experts' opinion.

An survey was carried out using a group of experts in the rice production domain to identify the most important rice SC processes, key success factors and the operational strategy. Agriculture domain experts who were involved in policy making and research with proven knowledge of the rice sector were interviewed to get their expert opinion. The best performers among 50 farmers were selected for the interviews including the president of the farmer organization and the best Farmer of the year. The interviews with best performers and experts were used as main resources for identification of the best practices. A survey with agriculture officers were conducted for further validation of the farmers' opinion.

An exploratory survey involved farmers and agriculture officers and there was a need to verify the degree of agreement or disagreement in the opinions held by each category. The Wilcoxon rank sum test was carried out to see whether there is a significant difference between the opinions of farmers' and those of agriculture officers. The study was carried with the Null Hypothesis 
$\left(\mathrm{H}_{0}\right)$ of "There is no significant difference between farmer opinion and agriculture officer opinion", where the Alternative Hypothesis $\left(H_{1}\right)$ "There is significant difference between farmer opinion and agriculture officer opinion". The total scores of both the farmers' and officers' surveys were categorized under the KSF and a scatter diagram was created by plotting farmers' score against the agriculture officers' score.

\section{Results and Discussion}

The results revealed that the $Z$ test statistic was $1.647(p=0.0994)$ and thus, indicating that there is no significant difference among the opinions of the farmers and those of the agriculture officers. Therefore, the needs expressed by the group of farmers and officers were considered together for further validation of the models and identification of the strategic needs and best practices appropriate for the management of rice SC. Based on the stakeholder perceptions, the KSF of rice SC chain were identified (Table 1).

Table 1. Key success factors identified for the rice supply chain

\begin{tabular}{ll}
\hline Mechanization & Flexibility of the chain \\
Knowledge and skill development & Training and knowledge \\
Quality improvement & Pre-planning \\
Risk management & Information technology \\
Information availability & Infrastructure development \\
Branding & Extension \\
Marketing network & Sustainability \\
Market information generation & Communication \\
Effective Storage facility/methods & Water management practices \\
Government policy implementation & Demanding rice varieties \\
Cost reduction & \\
\hline
\end{tabular}

The total scores of both the farmers' and officers' surveys on the KSF were between 1 and 5 . The score of 3 was selected based on the scatter diagram as the cutoff point based on which, the four areas were identified (Table 2) for further analysis.

Farmers' opinion was based on the existing practical situation and they made judgments on the narrower scope than the agriculture officers; e.g. famers concluded on their infrastructure facilities comparing with those of the nearby areas and hence, conclusions dawn may be not $100 \%$ accurate. Due to experience and exposure on the broader agricultural domain, the expectations of the agricultural officers were higher than those of the farmers and they are expecting operational and strategic improvement of areas identified in Table 2. 
Table 2. Four areas identified for further analysis of the rice supply chain

\begin{tabular}{|l|l|}
\hline State 1 & $\begin{array}{l}\text { Quality, storage (post- and pre-harvesting storage), cost, delivery } \\
\text { cost, flexibility, Branding, labour availability, market information } \\
\text { availability, marketing network, ability of getting profit (return to } \\
\text { investment), government policy implementation are the key } \\
\text { areas with lower performances. Both agriculture officers and } \\
\text { farmers emphasized the above mentioned factors with lower } \\
\text { performance construct existing gaps within rice supply chain. }\end{array}$ \\
\hline State 2A/State 2B & $\begin{array}{l}\text { Training and development is the factor under this area which has } \\
\text { low performance from farmers' perspective and slightly high in } \\
\text { agriculture officers' perspectives. Therefore, it can be considered } \\
\text { as a need of the farmers to be competitive in the market place. } \\
\text { Each and every farmer is unable to get equal opportunity for } \\
\text { training and development due the some constraints (such as } \\
\text { inappropriate training method, lack of trainers and resource } \\
\text { persons, lack of training materials, etc.). However, the selected } \\
\text { study sample of agriculture officers thought that they were } \\
\text { facilitating sufficient training opportunities for the farmers. } \\
\text { According to the interviews conducted with agriculture officers } \\
\text { they commented that with the available facilities they attempt } \\
\text { facilitating equal opportunities for all farmers. Therefore, they } \\
\text { ranked training above the average. Extension, sustainability, } \\
\text { information availability, knowledge sharing and communication, } \\
\text { availability of demanding rice varieties, knowledge and water } \\
\text { management practices are the areas at the current level both } \\
\text { farmers and agricultural officers had higher satisfaction. }\end{array}$ \\
\hline State 3 \\
$\begin{array}{l}\text { Pre-planning, Information technology, infrastructure and } \\
\text { maintenance are the some controversial factors where farmers } \\
\text { score is higher than officers score. }\end{array}$ \\
\hline
\end{tabular}

Each and every KSF in the rice SC directly or indirectly link with the strategic movement of the SC performance. The results also revealed that the adaptation of best practices to rice SC brings many benefits for structured management analysis of the processes involved in. The adaptation and application of the framework of SCOR model led to the identification of "best practices reference model" for knowledge and skill development, information availability and accessibility, risk management, mechanization and product development, quality improvement and sustainability. These areas ate the key strategic aspects to be addressed in enhancing SC strategies for the production of rice in Sri Lanka.

According to the national goal for rice sector improvement, a strategic vision for the rice sector development integrated with upstream and downstream linkages of the supply chain is needed. Based on the findings of this research, three states as a ladder were identified and developed (Figure 1), which is named as the rice supply chain development ladder (RSCDL). 


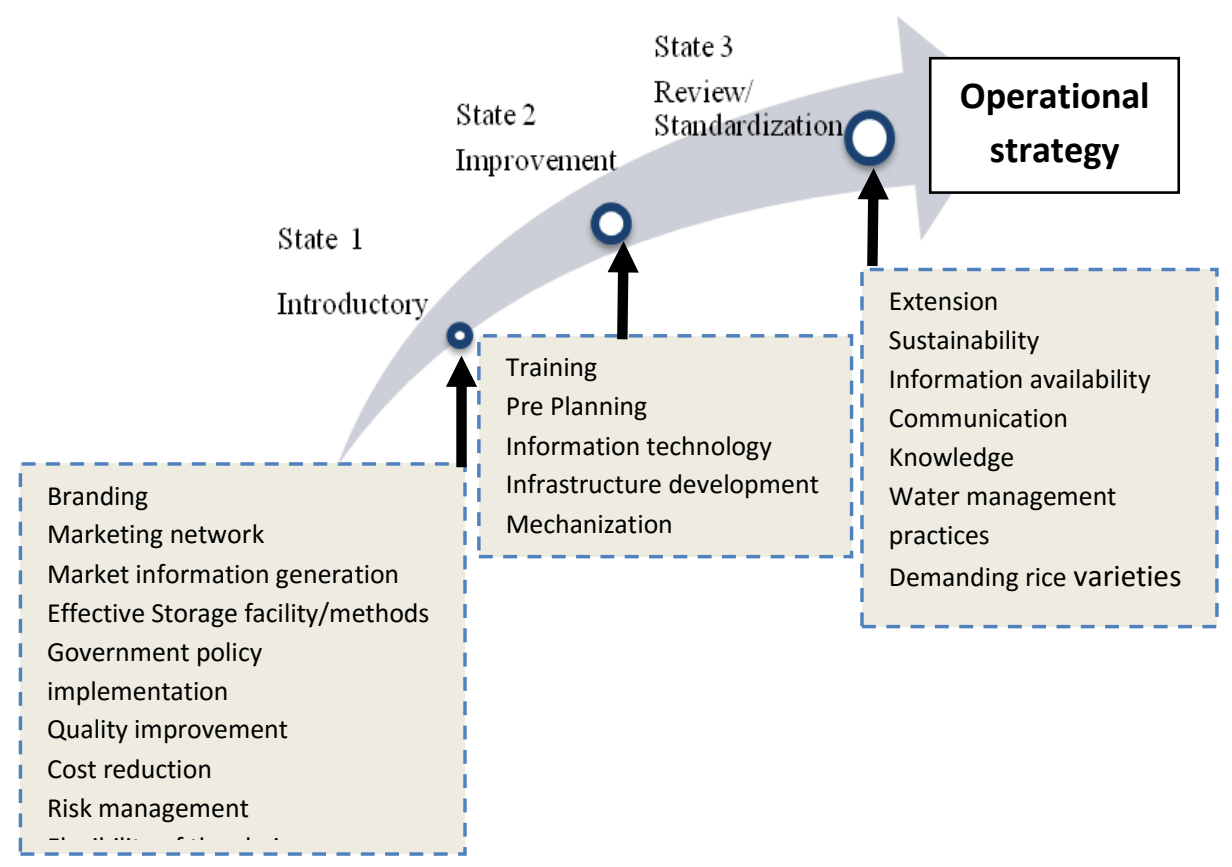

Figure 1. Rice supply chain development ladder

Table 3. The three different states of the rice supply chain development ladder

\begin{tabular}{|c|c|}
\hline State & Description \\
\hline State 1 - Introductory & $\begin{array}{l}\text { Most of the factors are at the initial stage of the supply } \\
\text { chain development and strive to develop in order to } \\
\text { achieve operational strategy. Factors badly need } \\
\text { improvement under this state because of the } \\
\text { nonexistence of strategies. }\end{array}$ \\
\hline State 2 - Improvement & $\begin{array}{l}\text { Success factors under this stage are gradually emerging, } \\
\text { but still some adjustments are needed to improve and } \\
\text { control the implementation. In the improvement state } \\
\text { both operational levels (farmers) and middle levels } \\
\text { (Agriculture officers) have realized the need for } \\
\text { improvement. Therefore, strategies can be made easily } \\
\text { in order to reach next state of the development ladder. }\end{array}$ \\
\hline $\begin{array}{l}\text { State } 3 \text { - } \\
\text { Review/Standardization }\end{array}$ & $\begin{array}{l}\text { Factors under this stage are well developed and } \\
\text { implemented. Best practices under this stage are } \\
\text { proven. Factors under this stage are more established } \\
\text { relative to the other stages. Therefore, there is only a } \\
\text { need to review and improve them in order to achieve } \\
\text { operational strategy. }\end{array}$ \\
\hline
\end{tabular}


The Figure 1 illustrates the ladder and the factors that are prominent at each state. The RSCDL contains introductory, improvement and review/ standardization states (Figure 1; Table 3). The RSCDL (Figure 1) model facilitates to identify AS-IS state, which corresponds to how activities (physical system) and decisions (decisional system) are currently performed, in the rice supply chain of the selected study site. These states can be different in different districts based on the various constraints. This development ladder can be used as a representation of the current AS-IS states of the rice SCKSF.

\section{References}

Cooper, M.C., Douglas M.L., Janus D. and Pagh D.J. (1997): Supply Chain Management: More than a New Name for Logistics, The Int. J. Logistics Managt. 8(1): 1-14.

Croxton, K.L., Sebastin J.G-D, Douglas M.L. and Dale S.R. (2001a): The Supply Chain Management Processes, The Int. J. Logistics Managt 12(2): 13-36.

Croxton, K.L. (2001b): The Order Fulfillment Process, The International Journal of Logistics Management, 12(2): 13-26.

https://depts.washington.edu/oei/resources/toolsTemplates/crit_success_factors.pdf

http://supply-chain.org

http://wps.pearsoned.co.uk/ema_uk_he_slack_opsman_4/17/4472/1144851.cw/

Rockart, J.F. (1979): "Chief Executive Define Their Own Data Needs" Harvard Business Review, March-April, pp. 81-93.

Leidecker, J.K. and Bruno, A.V. (1984): “Identifying and Using Critical Success Factors", Long Range Plan. 17(1): 23-32. 